Review Article

\title{
Bismuth as Smart Material and Its Application in the Ninth Principle of Sustainable Chemistry
}

\author{
Ayodele Temidayo Odularu \\ Department of Chemistry, University of Fort Hare, Private Bag X1314, Alice 5700, South Africa \\ Correspondence should be addressed to Ayodele Temidayo Odularu; 201106223@ufh.ac.za
}

Received 31 October 2019; Revised 30 April 2020; Accepted 11 June 2020; Published 22 July 2020

Academic Editor: Radhey Srivastava

Copyright (c) 2020 Ayodele Temidayo Odularu. This is an open access article distributed under the Creative Commons Attribution License, which permits unrestricted use, distribution, and reproduction in any medium, provided the original work is properly cited.

\begin{abstract}
This paper reports an overview of Green Chemistry and the concept of its twelve principles. This study focusses on the ninth principle of Green Chemistry, that is, catalysis. A report on catalysis, in line with its definition, background, classification, properties, and applications, is provided. The study also entails a green element called bismuth. Bismuth's low toxicity and low cost have made researchers focus on its wide applications in catalysis. It exhibits smartness in all the catalytic activities with the highest catalytic performance among other metals.
\end{abstract}

\section{Introduction}

1.1. Concept of Green Chemistry and Its Principles. At the start of the 1990s, almost thirty years ago, the definition and concept of Green Chemistry were first discovered [1]. Afterward, there has been global approval which led to the establishment of hundreds of programs and government inventions on Green Chemistry around the globe with foremost important programs located in Italy, the United Kingdom, and the United States of America [2]. Two groups of researchers defined Green Chemistry as the designed chemical processes and products to decrease or eradicate the use and generation of hazardous substances [2, 3]. Every reaction should have three green components of solvent, reagent/catalyst, and energy consumption to be identified as "green" [3, 4]. Green Chemistry is based on twelve principles, which could be used to create, design, or recreate materials, molecules, reactions, and processes, which are safe for human health and the environment $[3,5]$. Green Chemistry processes developed to date involve mostly all areas of chemistry, such as biochemistry, environmental, inorganic, organic, physical, and technological chemistry [3, 6, 7]. The basic principles of Green Chemistry cover a broad spectrum of synthetic organic synthesis, designing processes in organic synthesis to decrease byproduct/waste generation, decrease the use of hazardous chemicals/raw materials, and increase the use of safer or more environmentally safe solvents and (bio) catalysts, and renewable raw materials [8]. Additionally, Green Chemistry entails the most excellent approach to dispose waste and design of degradation process of chemical products subsequent to its use in order to support pollution prevention and sustainable development measures [9-11].

1.2. Green Chemistry. Maintenance of a green series of years is a battlefield of environmental activists, and to become green is becoming a trend in product marketing [3]. For the chemists, it is very important to be green in order to apply the principles of Green Chemistry to all aspects of chemical sciences, elementary and applied research, production, and education $[2,12]$.

1.2.1. Green Chemistry Definition. Environmental Pollution Agency defines Green Chemistry as chemistry which designs chemical products and processes, which are harmless, and, hence, prevents pollution formation [2]. Chemical products should be made so that they do not remain in the environment after application and that they are broken down into constituents which are harmless to the environment 
$[13,14]$. Saving based on the effective synthesis, without the use of "exotic" reagents, decreasing the required energy, and substituting organic solvents with water are important even at the laboratory level, while on the industrial scale, there are possible millions of savings [3]. As a propulsive research area, Green Chemistry tries to discover and sustain a balance between the use of natural resources, economic growth, and environmental conservation $[3,15]$.

1.2.2. Trends in Green Chemistry. Green Chemistry is a "plan for the design, development, and application of chemical processes and products which decrease or eradicate the use or production of substances which are hazardous to human health and the environment," and to achieve the main objectives of the green plan comes through numerous dominant trends $[3,16]$. These six trends are as follows:

(a) Research in the field of catalytic and biocatalytic reactions in order to get highly selective and pure compounds without the formation of toxic byproducts

(b) Seeking new materials, which are harmless and renewable, such as biomass

(c) Designing less toxic eco-friendly chemicals

(d) Discovering and assessing new alternative nontoxic and renewable reaction media, such as water, ionic liquids, and supercritical fluids

(e) Discovering and assessing new alternative reaction conditions, such as microwave, ultrasound, and light reacting

(f) Searching for alternative routes to purify poisoned air and water to improve their quality, such as photocatalytic reactions

With the realization of the set objectives, Green Chemistry changes the firm industrial practice of producing, polluting, and subsequent cleansing and in the belatedly twentieth century becomes the sensitivity of industrial ecology $[3,17]$.

Green Chemistry is a Hippocratic oath for chemists [17-19]. In order to preserve natural resources and the environment, a new cohort of scientists and technologists is being developed who will analyze economically the materials and processes used in production and development [10, 20]. Green Chemistry or ecologically harmless, harmless, and sustainable chemistry is the manufacture and application of chemical products and processes which decrease or eradicate the use and creation of hazardous substances [3, 21]. As a substitute for the risk of controlling exposure to harmful chemicals, Green Chemistry seeks to decrease and probably eradicate the threat, refusing the need for exposure control [3]. If no hazardous substance is used or produced, then, there is zero risks and there is no need to bother about removing the hazardous substance from the environment or restraining exposure to them [3]. In other words, Green Chemistry is about decreasing waste, raw materials, risks, energy, environmental impact, and cost [3, 17, 22, 23].
1.3. Principles of Green Chemistry. Paul Anastas of the United States (US) Environmental Pollution Agency (EPA) and John Warner (then of Polaroid Corporation) formulated and developed the twelve principles of Green Chemistry [24]. In 1998, they explained their meaning in practice in their Green Chemistry: Theory and Practice book. Principles of Green Chemistry address the decrease of hazardous or harmful substances from the synthesis, production, application of chemical products, and also signified research precedence for the development of Green Chemistry technologies [3, 24].

The twelve principles of Green Chemistry cover conceptions, such as the following $[3,24]$ :

the design of processes to take advantage of the quantity of raw materials which forms the product

the use of renewable material feedstock and energy sources

the use of safe, environmentally benevolent substances including solvents, when possible

the design of energy proficient processes

evading waste production, which is viewed as the ideal form of waste management

1.3.1. Twelve Principles of Green Chemistry. Paul Anastas and John Warner of EPA formulated and developed the twelve principles of Green Chemistry [2]. They explained their meaning in practice in their Green Chemistry: Theory and Practice book [2, 3]. The Green Chemistry principles talk about the decrease or removal of hazardous or unsafe substances from the synthesis, production, and application of chemical products $[3,25]$. It also deals with the reduction or eradication of hazardous chemical substances used for human health and the environment $[3,26]$. The requirements of all the twelve principles of the Green Chemistry process are impossible to be met at the same time when designing a Green Chemistry process, but it tries to apply as many principles as possible in certain phases of synthesis [3, 27-29].

(1) Prevention: the principle of prevention is the first principle of Green Chemistry. Prevention of waste generation is better and more favorable for humans and the environment and eventually cheaper than treating wastes, destroying them, and cleaning up waste after they have been created

(2) Atom economy: synthetic methods should try to take advantage of the incorporation of all materials used in the final product. Hence, this means that less waste will be created

(3) Less hazardous chemical synthesis: synthetic methods should avoid using or creating chemical substances toxic to humans and/or the environment

(4) Designating safer chemicals: chemical products should be designed to attain their desired function, as well as being as nontoxic as possible 
(5) Safer solvents and auxiliaries: auxiliary substances should be evaded where possible and as nonhazardous as possible when they are used

(6) Design for energy efficiency: energy requirements should be reduced and processes should be conducted at ambient temperature and pressures where possible

(7) Use of renewable feedstocks: when it is practical to do so, renewable feedstocks or raw materials are preferable to nonrenewable ones

(8) Reduce derivatives: unnecessary creation of derivatives, such as the use of protecting groups, should be reduced or avoided if possible; such steps require additional reagents and may create additional waste

(9) Catalysis: catalytic reagents which could be used in small quantities to repeat a reaction are superior to stoichiometric reagents (ones which are consumed in a reaction)

(10) Design for degradation: chemical products should be designed so that they do not pollute the environment; whenever their function is complete, they should break down into nonharmful products

(11) Real-time analysis for pollution prevention: analytical methodologies need to be further developed to permit real-time, in-process monitoring and control before hazardous substances are formed

(12) Naturally safer chemistry for accident prevention: when possible, the chemical substances in a process and the forms of those substances should be chosen to reduce risks, such as explosions, fires, and accidental releases

1.3.2. Purpose of Green Chemistry. The purpose of Green Chemistry in environmental protection and economic profit is accomplished through numerous prevailing tips, such as catalysis, biocatalysis, use of alternative renewable raw materials (biomass), alternative reaction media (water, supercritical fluids, and ionic liquids), alternative reaction conditions (microwave activation, mechanochemistry, and ultrasound), and new photocatalytic reactions [30,31].

Catalysis is a process whereby a substance called catalyst is added to speed up the rate of a reaction [32-34]. A minimum amount of catalyst can be used repeatedly because it is not consumed in the catalyzed reaction [34]. It provides a different pathway with lower activation energy in order to increase a reaction rate than the noncatalyzed mechanism [33]. In a catalyzed mechanism, a catalyst often reacts to form a provisional intermediate, which at that point restores the original catalyst in a cyclical manner. It does not reduce the reaction rate, which is typical of a reaction inhibitor. Even though it is not consumed by a reaction, secondary processes can deactivate, destroy, or inhibit it $[35,36]$. The reaction rate depends on the contact frequency of the reactants in the rate-determining step [37]. The catalyst often takes part in this slowest step; therefore, the amount of catalyst and its actions limit the reaction rates $[38,39]$. Catalysts can be categorized as either homogeneous or heterogeneous [40]. A homogeneous catalyst has its molecules distributed in the same phase (mostly in gaseous or liquid forms) with the reactants (s) molecules [40-43]. Substrate binding and product detachment, such as methyl acetate formation from acetic acid and methanol, and hydroformylation are examples of homogeneous catalysts. A heterogeneous catalyst has its molecules in a different phase from the reactant (s) molecules (usually gases and liquids) [40-43]. These phases can be adsorbed onto a solid catalyst surface [40-43]. The solid serves as a support in order to reduce the cost, increase the surface area, or enhance the efficiency $[43,44]$. In heterogeneous catalysis, reagents diffuse to the surface, and the product diffused from the surface could be rate determining [45]. Examples of heterogeneous catalysts are iron metal as the catalyst used for ammonia production by Haber process, sulfur (IV) oxide oxidation on vanadium $(\mathrm{V})$ oxide for tetraoxosulphate (VI) production by contact process and nanomaterials-based catalysts [46]. Usual secondary processes that affect heterogeneous catalysis are choking (polymeric side products cover the catalyst) and dissolution of heterogeneous catalysts in a solidliquid system or sublimate in a solid-gas system [47]. A third category comprises the enzymes and other biocatalysts [40].

1.4. Background. Catalysis is needed for the production of most industrially important chemicals and biochemically essential processes [34, 48]. It is the ninth principle of Green Chemistry (sustainable chemistry) [49]. Catalytic reactions are selected as being environmentally friendly because of the decreased amounts of waste generated when compared with noncatalyzed reactions [50-57]. Environmentally applied catalytic processes can be found in catalytic converters in automobiles and ozone hole dynamics. Catalysis could be classified as organometallic catalysts, electrocatalysts, photocatalysts, biocatalysts, and catalysts used in chemical synthesis reactions.

1.4.1. Organometallic Catalyst. Chemical synthesis and molecules' reactivities with metal-carbon bonds form organometallic complexes [58]. These organometallic complexes are different from organometal complexes because organometal complexes do not contain metal-carbon bonds. There have been reported cases of organometallic complexes acting as catalysts [58-62]. An inorganic chemist perceives organometallic catalysts as homogeneous catalysts [58]. Usually, organic catalysts need a higher amount of catalyst per unit amount of reactant (mol \% amount of substance) than transition metal (-ion)-based catalysts. However, these catalysts are often commercially available in bulk in order to reduce costs [58]. In the early 2000 s, organocatalysts were referred to as "new generation" and were competitive to traditional transition metal (-ion)-containing catalysts [63].

1.4.2. Electrocatalyst and Fuel Cell Catalyst. Many metalcontaining catalysts are applied to improve half-reaction rates which contain the fuel cell in fuel cell engineering [64-66]. A typical type of fuel cell electrocatalyst is established upon platinum nanoparticles [66, 67]. They are 
supported on slightly larger carbon particles [66, 67]. The platinum increases oxygen reduction rate to either hydrogen, hydrogen peroxide, or water when it is in contact with one of the electrodes in a fuel cell $[66,68]$. Fuel cells depend on catalysts for both anodic and cathodic reactions $[66,69,70]$.

1.4.3. Photocatalysis. Photocatalysis is the process whereby the catalyst absorbs visible light and gets promoted to an excited state [71-75]. At that moment, it goes through intersystem passage with the reactants and returns to the ground state without being consumed [76]. The excited state of the starting material will at that moment go through reactions it was unable to if irradiated directly [77, 78]. An example is the photocatalysis production of singlet oxygen $[79,80]$.

1.4.4. Biocatalysts. In biological science, enzymes are protein-based catalysts in metabolism and catabolism [81, 82]. In biocatalysis, enzymes are used to prepare various chemical products, such as acrylamide and high-fructose corn syrup. Most biocatalysts are enzymes, but the nonprotein-based groups of biomolecules also display catalytic properties, such as natural ribozymes and synthetic deoxyribozymes $[83,84]$. Biocatalysts can be assumed to be an intermediary between homogeneous and heterogeneous catalysts $[40,85]$. However, soluble enzymes are homogeneous catalysts, and membrane-bound enzymes are heterogeneous [86]. Some of the factors which affect catalysts and enzymes' activities are enzyme's concentration, substrate, and products, as well as $\mathrm{pH}$ and temperature [87].

1.5. Nanocatalysts (Nanomaterial-Based Catalysts). In nanocatalysis, the nanocatalysts are nanomaterials with catalytic actions [88-90]. They were discovered to have wide applications [88, 89, 91]. Additionally, nanozymes are nanocatalysts with enzyme imitating activities [92-94].

1.5.1. Tandem Catalysis. In tandem catalysis, there is a coupling of two or more different catalysts in a one-pot reaction [95-99]. Biocatalysts are often used [97-99].

\section{Synthetic Chemist, Chemical Processes, and Catalysts}

Challenges confronted by synthetic organic chemists when trying to use extremely functionalized small molecules are changing very fast because of new safety and economic requirements enforced by society [97]. Seeking new ways to achieve (i) chemo-, region-, and stereoselectivity, (ii) functional group tolerance, and (iii) reaction yields have always been existing, but at the end of last century, new awareness arose to produce chemicals and materials also under mild reaction conditions, such as room temperature and air stability [97]. Additionally, synthetic chemists propose reactions with other conditions, such as safety, taking place at room temperature, absence of atmospheric protection to prevent Earth's ozone layer depletion, use of catalysts, and using cheap and safe solvents like water for a successful application of new chemical process [97]. Being mindful of these challenges, in the case of catalysts, biocatalysts or whole microorganisms (natural catalysts which are biocompatible, biodegradable, and nontoxic) have received enormous growth for the synthesis of small organic molecules containing chiral units [97]. They are applied in fine chemical industry [97]. The two potential combinations are organic-/biocatalysts and metal-/biocatalysts [97].

2.1. Autocatalysis. Contrary to other types of catalysts, in autocatalysis, the catalyst is a product of the whole reaction. In essence, the reaction is autocatalyzed or speeds itself up $[100,101]$.

\section{Applications of Catalysis}

Applications of catalysis can be seen in generating valuable materials in the petroleum industry, catalytic converters, synthetic fuels, fuel cells, catalytic heaters, bulk chemicals, bulk polymers, fine chemicals, carbonylation processes, pharmaceuticals, food processing, and Green Chemistry [102-105].

3.1. Petroleum Industry. In the petroleum industry, catalysis is used thoroughly to refine petroleum in different ways [106]. These ways are (i) alkylation, (ii) catalytic cracking (long-chain hydrocarbons are broken into smaller hydrocarbons), (iii) naphtha reforming, and (iv) steam reforming (hydrocarbon conversion into synthetic gas) [106].

3.2. Catalytic Converters. Catalysis is also used to treat the exhaust from fossil fuels' burning [107]. Catalytic converters usually consist of platinum and rhodium [108]. They break down some harmful byproducts of automobile exhaust [107].

3.3. Synthetic Fuels. In synthetic fuels, the Fischer-Tropsch process is used to synthesize hydrocarbons from synthetic gas $[109,110]$. Iron-catalyzed water-gas shift reaction is used to process synthetic gas $[109,111]$. Inorganic and biocatalysts are used to process biodiesel and related biofuels [112-114].

3.4. Catalytic Heaters. Combustible fuel supplied to catalytic heaters is used to produce flameless heat [115].

3.5. Bulk Chemicals. Catalytic oxidation (usually with oxygen) is used in the manufacture of some industrial chemicals, such as trioxonitrate (V) acid, tetraoxosulphate (VI) acid (by contact process), and terephthalic acid $[116,117]$. Hydrogenation is also used to manufacture other chemicals on a large scale, such as ammonia (by HaberBosch process) as shown in the following $[117,118]$ : 


$$
\mathrm{N}_{2}(\mathrm{~g})+3 \mathrm{H}_{2}(\mathrm{~g}) \longrightarrow 2 \mathrm{NH}_{3(\mathrm{~g})}
$$

3.6. Bulk Polymers. Ziegler-Natta catalysts are used to generate bulk polymers [119]. Acid-base catalysis is used to produce isocyanates, polyamides, and polyesters [120].

3.7. Fine Chemicals. Some of the catalytic reactions used to manufacture fine chemicals on a large scale are FriedelCrafts reaction and Heck reaction [121, 122].

3.8. Carbonylation Processes. Metal catalysts are used during hydroformylation and Monsanto (Cativa) acetic acid processes [123].

3.9. Pharmaceuticals. Nguyen et al. stated that more than half of the drugs used presently are chiral compounds [124]. Approximately ninety percent of the previous drugs were sold as racemates containing an equimolar mixture of two enantiomers [124]. Numerous isomers of chiral drugs show clear differences in biological activities, such as metabolism, pharmacokinetics, pharmacology, and toxicology [124]. Enantioselective catalysts are used to produce various pharmaceuticals because they contain bioactive compounds that are chiral [124-127].

3.10. Food Processing. Nickel catalyst as a metal catalyst is used in the hydrogenation (reaction with hydrogen gas) of fats to produce margarine [128]. Biocatalysts are used for other food products [129-131].

3.11. Green Environment. Catalysis influences the environment by enhancing effectively the industrial processes $[30,132,133]$. Catalysis's direct role is displayed in its ozone $\left(\mathrm{O}_{3}\right)$ breakdown using chlorine [134]. The direct role catalysis plays in the environment is the breakdown of chlorine free radicals $[135,136]$. Ultraviolet radiation activities on chlorofluorocarbons (CFCs) form these radicals $[137,138]$. The processes involved are displaced in equations (2) and (3). The dot is a code to signify that the species has an unpaired electron.

$$
\begin{aligned}
& \mathrm{Cl}^{-}+\mathrm{O}_{3} \longrightarrow \mathrm{ClO}^{-}+\mathrm{O}_{2} \\
& \mathrm{ClO}^{-}+\mathrm{O} \longrightarrow \mathrm{Cl}^{-}+\mathrm{O}_{2}
\end{aligned}
$$

The categories, classification, and applications of catalysis are shown in Figure 1.

\section{Bismuth and Green Catalysis}

4.1. Bismuth. According to the Royal Society of Chemistry, although bismuth has been known as early as 1400 [139]. It was frequently bemused with lead because it was likewise a heavy metal with a low melting point $[139,140]$. In 1753, a French chemist, Claude Geoffroy the Younger, was the first to prove that bismuth was distinct from lead [139-141]. The word "bismuth" is a Latinized version of an Old German word, "wismuth" or "white substance," probably named after the element's white oxide $[139,140]$. Bismuth (Bi) is brittle, coarsely crystalline, hard, and lustrous metal [139]. It has an atomic number of 83 , an atomic mass of 208.98, a density of $9.7 \mathrm{~g} / \mathrm{cm}^{3}$, a melting point of $271.3^{\circ} \mathrm{C}$, and a boiling point of $1837 \mathrm{~K}[139,141,142]$. It is also the most metallic and least abundant element in the nitrogen group (Group 15 (VA) of the periodic table) [140]. In spite of bismuth's location in the midst of toxic heavy metals in the periodic table, bismuth and its compounds are extraordinarily harmless [140, 141]. It is extraordinary from all other metals by its color-gray-white with a reddish tinge (pinkish stain) [139]. Bismuth forms chemical compounds in oxidation states of +3 and $+5[139,140]$. Numerous bismuth compounds are less toxic than table salt (sodium chloride) [141]. As a result of this, bismuth is unique among the heavy metals, and this has earned it the status of a "green element" [142]. Bismuth compounds are used as catalysts in the production process of synthetic fiber and rubber $[143,144]$. Other uses of bismuth are in fire detectors and extinguishers when they form alloys with other metals, such as cadmium, iron, lead, and tin at low melting point [139]. Bismuth alloys are also used to make sharp castings of objects [145].

4.2. Green Catalysis. In order to increase green catalysts' awareness, bismuth catalysts have become a major focus [146]. In the last twenty years ago, chemists began to revive the chemistry of organobismuth derivatives and bismuth catalysts [147].

Bismuth as a posttransition metal is a very useful heavy metal compared with other heavy metals (arsenic, cadmium, lead, and mercury) because of its relatively low toxicity and other distinct properties [148-150]. This has led to its various uses in various fields, such as alloy industries, contact lenses, cosmetics, electronics, greases, lubricating oils, medicines treatment, metallurgy, nuclear reactor cooling solutions, semiconductors, sugar purification reagents, and washing solution [146]. In addition to these bismuth's versatile applications, the low toxicity of its salts linked with low cost made them smart to be applied as catalysts [146].

On a different note, researchers discovered that the presence of bismuth and its compounds in cosmetics (lipstick) and pharmaceuticals could cause damage to the liver, kidney, and nervous system $[148,150]$. In other words, bismuth could be considered as one of the potential toxins, which has an adverse effect on motor neutrons $[148,151]$.

Despite the fact of the mild damage, the determination by effective methods is very important, though the amount will not deteriorate its merits when compared with other heavy metals for practical application purposes $[152,153]$. The reported methods used to determine bismuth are atomic spectrometry (AS), electrochemical techniques, electroscopic measurements, inductively coupled plasma spectrometry (ICPS), molecular absorptiometry, nuclear techniques, and X-ray fluorescence spectrometry (XRFS) [146]. 


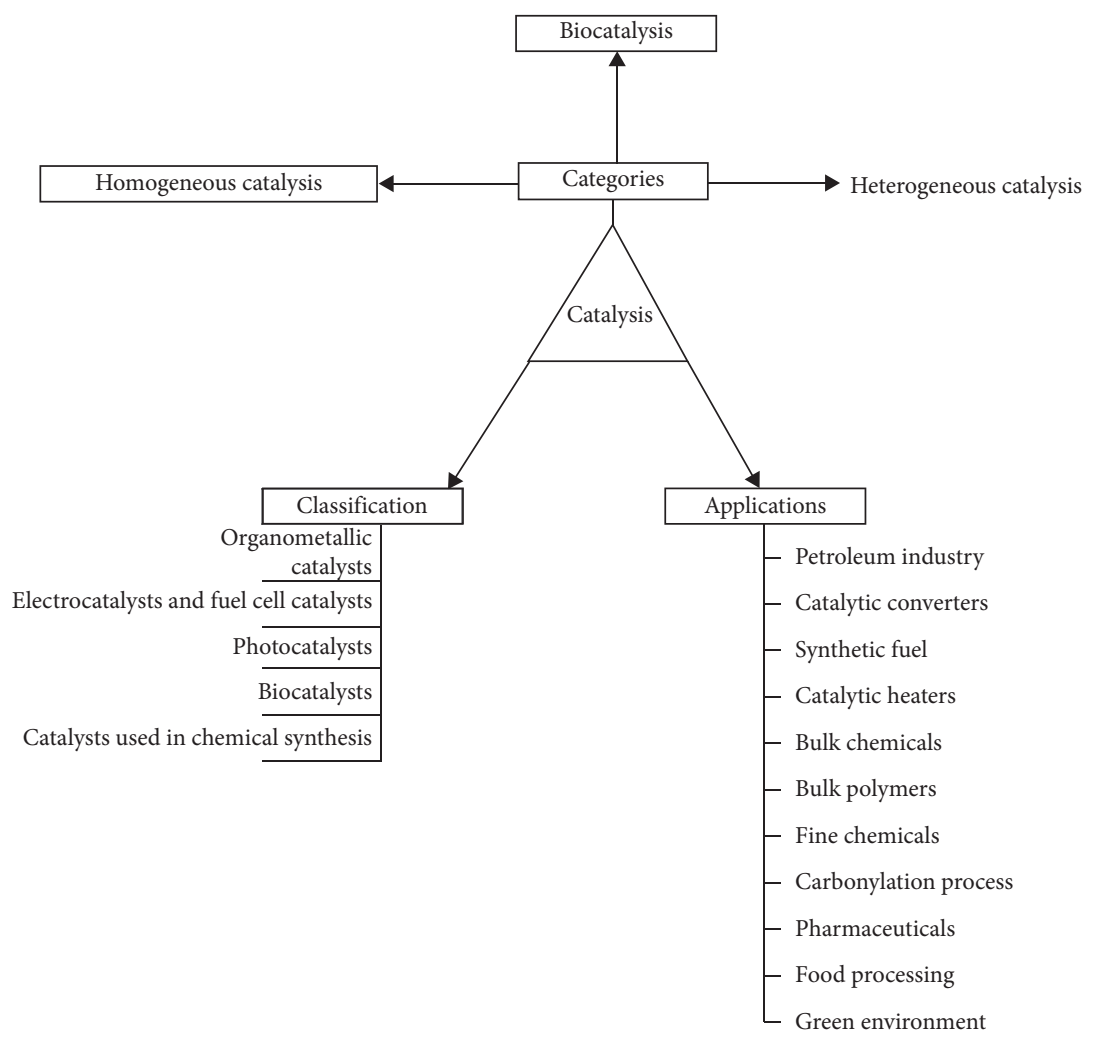

FIgURE 1: Categories, classification, and applications of catalysis.

This study aimed at the relevance of bismuth as a participant in catalysis. The consideration for bismuth as a catalyst for this study is due to its nontoxic nature and low cost.

4.2.1. Bismuth Catalytic Activities. From the aforementioned types of catalysis and its wide application, the question to ask is, "which catalytic roles does bismuth with its compounds perform to justify being termed a smart material?" In response to the question, bismuth belongs to the category of heterogeneous catalysis [154, 155]. It can be applied as an electrocatalyst, a photocatalyst, a chemical synthetic reaction nanocatalyst, and others [89, 156, 157].

4.2.2. Bismuth as Electrocatalyst and Fuel Cell Catalyst. According to Barón-Jaimez, in previous times, heavy metals were extracted and processed industrially [158]. Today, the presence of heavy metals, such as cadmium and lead ions in the food chain, has led to great global interest in the detection because of its adverse impacts above permissible levels for humans [158]. For numerous centuries, mercury electrodes were used to detect heavy metals [158]. With recent regulations and mercury's high toxicity, innovative options for its replacement as an electrode in electroanalytical techniques were investigated [118]. Bismuth electrodes were positioned as an option to mercury electrode because of its numerous characteristics comparable to mercury and its low toxicity [158].
With electrochemistry development, bismuth-modified electrodes have been used widely in the electroanalysis of an electrochemical sensor because of its low toxicity [158-162]. An enhanced bismuth film enclosed single-walled carbon nanotube (Bi/SWNT) composite was used effectively to fabricate an electrochemical sensor for the highly sensitive detection of trace chromium (IV) in actual samples with a fairly low $0.036 \mu \mathrm{M}$ detection limit [163]. Bismuth alloy films with other metals, such as antimony (Sb), mercury (Hg), and tin (Sn), have been confirmed to act better in stripping voltammetric determination of cadmium(II) than only bismuth film electrode [164, 165].

Apart from the use of bismuth in metal detection, bismuth-modified electrodes in the form of bismuth sulfide nanorod-modified glassy carbon electrode (GCE) can also be used to determine other substances, such as ascorbic acid $[166,167]$. Physical adsorption of Bi (III) on the platinum electrode surface displayed admirable linearly electrocatalytic performances to glucose oxidation [168]. Bismuth's electrocatalytic properties of intermetallic nanocrystallites offer the possibility as fuel cell anode catalysts as confirmed in the high activity platinum/bismuth nanocrystallite as a fuel cell anode catalyst for methanolic acid or methanol oxidation [169].

4.2.3. Bismuth-Based Photocatalysts. Bismuth-based photocatalysts usually exhibit high efficiency and good catalytic performance [170]. There is great effectiveness of bismuth molybdate $\left(\mathrm{Bi}_{12} \mathrm{MO}_{20}\right)$, bismuth oxyhalide, bismuth titanate, 
$\mathrm{Pt} / \mathrm{BiOI}$ nanosheets, bismuth tungstate $\left(\mathrm{Bi}_{2} \mathrm{WO}_{6}\right)$, bismuth vanadates $\left(\mathrm{BiVO}_{4}\right)$, and other composites' catalysts $\left(\mathrm{CuBi}_{2} \mathrm{O}_{4} / \mathrm{WO}_{3}, \mathrm{Bi}_{2} \mathrm{O}_{3}-\mathrm{TiO}\right)$ under visible light which were proved to be photoactive [171]. Bismuth improves the $\mathrm{TiO}_{2}$ photocatalytic property than only $\mathrm{TiO}_{2}[172,173]$. Either $\mathrm{Bi}$ or $\mathrm{B}$ separately doped $\mathrm{TiO}_{2}$ or $\mathrm{Bi}-\mathrm{B}$ codoped samples displayed improved photocatalytic activities to the acid orange degradation and 2, 4-dichlorophenol under visible light irradiation $[174,175]$. A combination of bismuth hydroxide with $\mathrm{BiOCl}$ provided five times excellent photocatalytic activity to remove aqueous $\mathrm{RhB}$ under visible light irradiation than Degussa P25 $\left(\mathrm{TiO}_{2}\right)$ [176].

\subsubsection{Bismuth Compounds' Good Catalytic Success toward} Chemical Synthetic Reactions. Bismuth compounds, such as bismuth phosphotungstate, were reported to catalyze many chemical reactions because of its high catalytic activity [148]. Some of the chemical reactions are the syntheses of cyclohexyl acetate heterogeneous and cyclohexyl acetate. The $\mathrm{Bi}_{2} \mathrm{SiO}_{5} / \mathrm{TiO}_{2}$ displayed excellent catalytic activities in gasphase epoxidation to propylene oxide by molecular oxygen [177]. $\mathrm{Bi}_{2} \mathrm{Cl}_{3} / \mathrm{SiO}_{2}$ might also act as a very effective and ecofriendly heterogeneous Lewis acid catalyst during the synthesis of the Paal-Knorr pyrrole in hexane at room temperature [178-181].

4.2.5. Bismuth as Binary Catalysts and Nanocatalysts. The study revealed that platinum $(\mathrm{Pt})$ and Pt-based catalysts are generally used in Direct Glucose Fuel Cells (DGFCs) because they possess high catalytic activities on glucose oxidation reaction (GOR) [182, 183]. The high abundance of glucose in nature, ease of preparation from biomass, nontoxic nature, and safe for storing justified it as a renewable and clean energy source, as well as a promising alternative fuel $[16,182]$. Research on glucose electrocatalytic oxidation attracted high attention due to its relevance to the use of DGFCs [16]. A complete GOR has theoretical energy of $2870 \mathrm{~kJ} \mathrm{~mol}^{-1}$, while the catalytic process could generate up to 24 electrons for one molecule of glucose [16].

In recent times, some noble metals' catalysts were developed for DGFCs to increase the catalytic activity. On the contrary, only partial glucose oxidation took place basically, and two electrons were free per molecule of glucose. In other words, there is amply room to develop new catalysts with lesser catalyst poisoning, improved stability, and greater efficiency for sufficient actual use [182]. In spite of the consideration of Pt as a suitable catalyst for GOR, its intermediates which are produced from GOR freely poisoned (infected) it [182]. Another challenge is the rather high cost of Pt metal to bring it to its actual use. These challenges resulted in developing other catalysts with much catalytic activity and enhanced catalytic performance toward GOR [182].

4.3. Other Catalytic Activities of Bismuth. Other catalytic activities of bismuth are piezocatalysis, pyrocatalysis, and tribocatalysis.
4.3.1. Piezocatalysis of Bismuth. Recently, the oxygen reduction reaction (ORR) was used to generate hydrogen peroxide $\left(\mathrm{H}_{2} \mathrm{O}_{2}\right)$ via a green path [184]. Here, a piezocatalyst approach is introduced to acquire $\mathrm{H}_{2} \mathrm{O}_{2}$ over bismuth oxychloride ( $\mathrm{BiOCl})$ via an ORR pathway. Piezoresponse force microscopy (PFM) was used directly to characterize the piezoelectric response of $\mathrm{BiOCl}$. The $\mathrm{BiOCl}$ showed the catalytic performance to generate $\mathrm{H}_{2} \mathrm{O}_{2}\left(28 \mu \mathrm{mol} \cdot \mathrm{h}^{-1}\right)$ merely from $\mathrm{O}_{2}$ and $\mathrm{H}_{2} \mathrm{O}$ above the $\mathrm{H}_{2} \mathrm{O}_{2}$ average level generated by solar-to-chemical processes. A piezocatalyst method proposed with ultrasonic waves 8 would generate alternating electrical fields over $\mathrm{BiOCl}$. This can drive electrons to react with $\mathrm{O}_{2}$ and $\mathrm{H}_{2} \mathrm{O}$ to form $\mathrm{H}_{2} \mathrm{O}_{2}$ [184]. Photocatalysis could also be combined (synergized) with piezocatalysis of bismuth oxychloride to degrade organic pollutants and for dye decomposition $[185,186]$.

4.3.2. Pyrocatalysis of Bismuth. The pyrocatalysis of bismuth is a potential in dye wastewater decomposition via harvesting cold-hot fluctuation thermoenergy [187]. They are also candidates for dye degradation $[188,189]$ and have applications to renewable energy production and environmental remediation [190].

4.3.3. Tribocatalysis of Bismuth. In tribocatalysis of bismuth, partial oxidation of bismuth compounds at high temperatures has effects on their lubrication characteristics in relation to the nature of the bismuth compound [191-193].

Another Pt group metal called palladium (Pd) is well known as a promising potential electrocatalyst due to its Earth's abundance and has a fairly lesser cost than Pt [194]. Presently, Pd-based catalysts were studied for alcohol, glucose, and formic acid electrooxidation in alkaline medium [195]. Conversely, there is still a need to improve and develop novel catalysts with an extraordinary catalytic activity and enhanced stability for commercial applications in DGFCs [196, 197].

In recent times, it was revealed that catalytic performance and infection tolerance of catalysts could be improved extensively in electrooxidation of organic molecules by influencing $\mathrm{Pt}$ and $\mathrm{Pd}$ catalysts with foreign metals, such as bismuth (Bi), gold $(\mathrm{Au})$, rhodium $(\mathrm{Rh})$, and tin $(\mathrm{Sn})$, as shown in Table 1 [182]. The electrocatalytic enhancement ensued from metal's modified catalytic surface with supporting species controls the adsorption of intermediates on active sites of the working electrocatalyst and then increases the catalytic actions [182].

Among these aforementioned modifiers, the cost of $\mathrm{Bi}$ is fairly lesser than the others and was proved as an ideal foreign metal to enhance catalytic performance [182]. Additionally, Bi has been applied in Pt-based and Pd-based catalysts for glycerol and ethanol oxidation reactions, respectively [182]. It was also stated that the modification of $\mathrm{Bi}$ on noble metal catalysts is attained by an irreversible adsorption reaction [182].

In Chen et al.'s preliminary DGFCs study, the Pd-based binary anode catalysts were examined on GOR activities with a Pt sheet cathode for the oxygen reduction reaction [182]. 
TABLE 1: Comparison of glucose oxidation reaction (GOR) performance between different binary Pd-based catalysts.

\begin{tabular}{lccc}
\hline \multirow{2}{*}{ Anodic catalyst } & \multicolumn{2}{c}{ Onset potential $(\mathrm{V}$ vs. $\mathrm{Hg} / \mathrm{HgO})$} & \multicolumn{2}{c}{ Anodic peak for forward scan } \\
& & Peak potential (V vs. Hg/HgO) & 3.5 \\
\hline $\mathrm{Pd}-\mathrm{Rh} / \mathrm{C}$ & -0.55 & 0.05 & 3.7 \\
$\mathrm{Pd}_{2}-\mathrm{Sn}_{2} / \mathrm{C}$ & -0.58 & 0.08 & 2.5 \\
$\mathrm{Pd}-\mathrm{Au} / \mathrm{C}$ & -0.45 & -0.15 & 9.2 \\
$\mathrm{Pt}-\mathrm{Bi} / \mathrm{C}$ & -0.50 & -0.30 & 29.5 \\
$\mathrm{Pd}-\mathrm{Bi} / \mathrm{C}$ & -0.55 & -0.05 & \\
\hline
\end{tabular}

TABLE 2: Comparison of the home-made direct glucose functionalized C (DGFC) power output on different binary Pd-based catalysts: Pd$\mathrm{Ni} / \mathrm{C}, \mathrm{Pd}-\mathrm{Bi} / \mathrm{C}$, and $\mathrm{Pd}-\mathrm{Te} / \mathrm{C}$.

\begin{tabular}{lcc}
\hline Anode catalyst & OCV $(\mathrm{V}$ vs. $\mathrm{Hg} / \mathrm{HgO})$ & ${\text { Power density }\left(\text { in } \mathrm{mW}^{-1} \mathrm{~cm}^{-1}\right.}^{\mathrm{Pd}-\mathrm{Ni} / \mathrm{C}}$ \\
$\mathrm{Pd}-\mathrm{Bi} / \mathrm{C}$ & 0.90 & 0.8 \\
$\mathrm{Pd}-\mathrm{Te} / \mathrm{C}$ & 0.95 & 1.5 \\
\hline
\end{tabular}

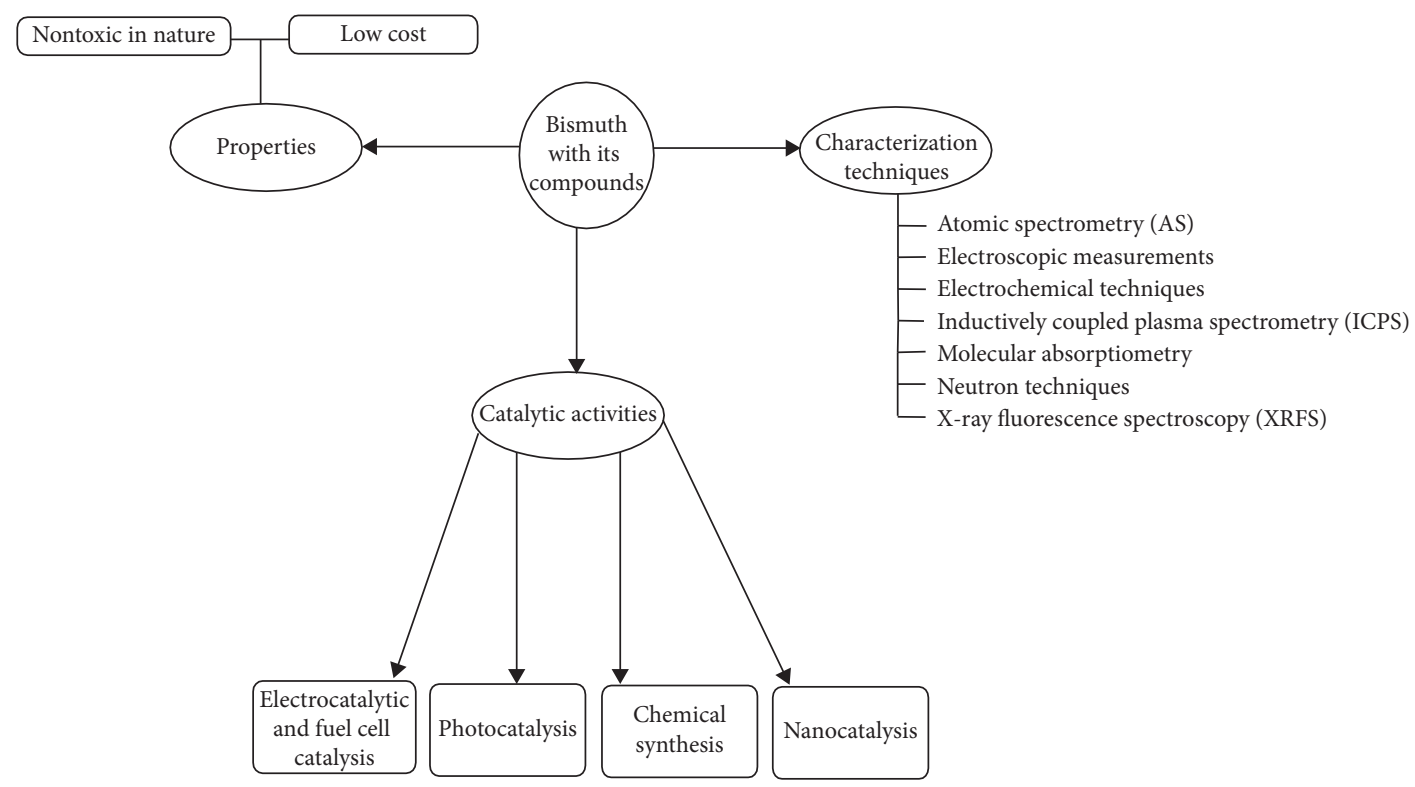

FIGURE 2: Bismuth catalytic activities.

They observed that the binary Pd-Bi/C catalyst achieved a higher power output of $1.5 \mathrm{~mW} \mathrm{~cm}^{-2}$ than those of $\mathrm{Pd}-\mathrm{Ni} / \mathrm{C}$ $\left(0.8 \mathrm{~mW} \mathrm{~cm}^{-2}\right)$ and $\mathrm{Pd}-\mathrm{Te} / \mathrm{C}\left(0.6 \mathrm{~mW} \mathrm{~cm}^{-2}\right)$ catalysts when being brought together into a home-made direct glucose fuel cell as shown in Table 2 [182].

In addition, Chen et al. also synthesized binary palladium-bismuth nanocatalysts supported on functionalized multiwalled carbon nanotubes (Pd-Bi/C) using the one-pot polyol method [182].

The carbon nanosupport is essential for giving smaller size and higher dispersion of metal nanoparticles, which increases the electrocatalytic activity [182]. It was observed that carbon nanotubes (CNTs) are perfect carbon nanosupport due to their high electrical conductivity, high surface area, and long-term stability [182].
In recent times, it was confirmed that surface-modified multiwalled carbon nanotubes (MWCNTs) could improve the dispersion of decorated metal nanoparticles because of the synergistic impact of functional groups. Chen et al. chose cMWCNT as a carbon support material for Pd-Bi catalysts in GOR studies [182].

The synthesized $\mathrm{Pd}-\mathrm{Bi} / \mathrm{C}$ catalysts have a metal particle range from 5.25 to $12.98 \mathrm{~nm}$ and were studied for alkaline electrocatalytic glucose oxidation reaction (GOR) [142]. Physical features of the catalysts were characterized by X-ray diffraction (XRD), scanning electron microscopy with energy-dispersive X-ray spectroscopy (SEM-EDS), transmission electron microscopy (TEM), and X-ray photoelectron spectroscopy (XPS) [182]. 
Cyclic voltammetry (CV), linear sweep voltammetry (LSV), Tafel analysis, and chronoamperometry (CA) were used to determine the electrochemical activities and compare the electrochemical active surface area (ECSA), GOR onset potential, GOR peak current density, Tafel slope, poisoning (infection) rate, and cycling stability of the $\mathrm{Pd}-\mathrm{Bi} /$ $\mathrm{C}$ catalysts [182]. They observed that Pd-Bi/C $(1: 0: 14)$ could extensively enhance the electrocatalytic activity on GOR about $40 \%$ times higher than $\mathrm{Pd} / \mathrm{C}$, as well as having a 3.7fold lower poisoning rate [182]. The in-use stability of $\mathrm{Pd}-\mathrm{Bi} /$ $\mathrm{C}(1: 0: 14)$ was also enhanced extraordinarily according to the results of the 200 cycling CV test [182].

In summary, in the alkaline GOR medium, the highest Pd-Bi/C-catalyzed GOR current density of $29.5 \mathrm{~mA} \cdot \mathrm{cm}^{-1}$ was achieved by Chen et al. [182].

Bismuth catalytic activities are summarized in Figure 2.

\section{Conclusion and Future Research}

The study deals with the concept and purpose of Green Chemistry, as well as the twelve principles of Green Chemistry. Emphasis was focused on "catalysis", the ninth principle of Green Chemistry, and its relationship with bismuth properties of bismuth's low toxic profile and low cost enables it to be smart to be a useful catalyst. Therefore, it could be applied as electrocatalysts, photocatalysts, catalysts in chemical synthetic reactions, nanocatalysts, piezocatalysts, pyrocatalysts, and tribocatalysts.

Future research will entail comparative studies of binary platinum group bismuth catalysts/nanocatalysts and binary nonplatinum group bismuth catalysts/nanocatalysts, as well as their antibacterial applications.

\section{Data Availability}

The data in the document and figures used to support the findings on this study are included within the research article.

\section{Conflicts of Interest}

The author declares no conflicts of interest.

\section{Acknowledgments}

The author appreciates the financial assistance from Govan Mbeki Research and Development Centre (GMRDC).

\section{References}

[1] B. A. De Marc, S. E. Rechelo, E. G. Tótoli, A. C. .. Kogawa, and H. R. Salgado, "Evolution of green chemistry and its multidimensional impacts: a review," Saudi Pharmaceutical Journal, vol. 27, pp. 1-8, 2019.

[2] P. Anastas and N. Eghbali, "Green chemistry: principles and practice," Chemistry Society Reviews, vol. 39, no. 1, pp. 301-312, 2010.

[3] A. Ivanković, M. Bevanda, and S. Talić, "Review of the 12 principles of green chemistry and practice," International Journal of Sustainable and Green Energy, vol. 6, pp. 39-48, 2017.
[4] M. A. Dubé and S. Salehpour, "Applying the principles of green chemistry to polymer production technology," Macromolecular Reaction Engineering, vol. 8, no. 1, pp. 7-28, 2014.

[5] P. T. Anastas and E. S. Beach, "Green chemistry: the emergence of a transformative framework," Green Chemistry Letters and Reviews, vol. 1, pp. 9-24, 2008.

[6] M. J. Mulvihill, E. S. Beach, J. B. Zimmerman, and P. T. Anastas, "Green chemistry and green engineering: a framework for sustainable technology development," Annual Review of Environment and Resources, vol. 36, no. 1, pp. 271-293, 2011.

[7] O. V. Kharissova, B. I. Kharisov, C. M. O. González, Y. P. Méndez, and I. López, "Greener synthesis of chemical compounds and materials," Royal Society Open Science, vol. 6, pp. 1-41, 2019.

[8] M. Gupta, S. Paul, and R. Gupta, "General aspects of basic principles of green chemistry with applications," Current Science, vol. 99, pp. 1341-1360, 2010.

[9] H. I. Abdel-Shafy and M. S. M. Mansour, "Solid waste issue: sources, composition, disposal, recycling, and valorization," Egyptian Journal of Petroleum, vol. 27, no. 4, pp. 1275-1290, 2018.

[10] L. Marcelino, J. Sjöström, and C. A. I. Marques, "Socialproblematization of green chemistry: enriching systems thinking and social sustainability by education," Sustain, vol. 11, 2019.

[11] S. E. Crawford, T. Hartung, H. Hollert et al., "Green toxicology: a strategy for sustainable chemical and material development," Environmental Sciences Europe, vol. 29, no. 1, 2017.

[12] N. Winterton, "Green chemistry: deliverance or distraction?" Clean Technologies and Environmental Policy, vol. 18, no. 4, pp. 991-1001, 2016.

[13] R. C. Thompson, C. J. Moore, F. S. vom Saal, and S. H. Swan, "Plastics, the environment and human health: current consensus and future trends," Philosophical Transactions of the Royal Society B: Biological Sciences, vol. 364, no. 1526, pp. 2153-2166, 2009.

[14] T. Welton, "Solvents and sustainable chemistry," Proc. R. Soc, vol. A471, pp. 1-26, 2015.

[15] A. R. Romeiro, "Desenvolvimento sustentável: uma perspectiva econômico-ecológica," Estudos Avançados, vol. 26, no. 74, pp. 65-92, 2012.

[16] P. A. Owusu and S. Asumadu-Sarkodie, "A review of renewable energy sources, sustainability, issues and climate cane migration," Cogent Engineering, vol. 3, pp. 1-14, 2016.

[17] P. T. Anastas and J. B. Zimmerman, "The periodic table of the elements of green and sustainable chemistry," Green Chemistry, vol. 21, no. 24, pp. 6545-6566, 2019.

[18] H. Frank, J. E. Forman, and D. Cole-Hamilton, "Chemical weapons: what is the purpose? The hague ethical guidelines," Toxicological \& Environmental Chemistry, vol. 100, no. 1, pp. 1-5, 2018.

[19] R. Sheldon and J. C. Warner, "Aiming for that goal of zero emission," in Green Chem: Theory Prac, p. 134, Oxford University Press, Oxford, UK, 1998.

[20] M. Karpudewan, Z. Ismail, and W.-M. Roth, "Ensuring sustainability of tomorrow through green chemistry integrated with sustainable development concepts (SDCs)," Chemistry Education Research and Practice, vol. 13, no. 2, pp. 120-127, 2012. 
[21] T. Keijer, V. Bakker, and J. C. Slootweg, "Circular chemistry to enable a circular economy," Nature Chemistry, vol. 11, no. 3, pp. 190-195, 2019.

[22] P. Marion, B. Bernela, A. Piccirilli et al., "Sustainable chemistry: how to produce better and more from less?" Green Chemistry, vol. 19, no. 21, pp. 4973-4989, 2017.

[23] D. A. Taylor, "Principles into practice setting the bar for green chemistry," Environmental Health Perspectives, vol. 118, no. 6, pp. A254-A257, 2010.

[24] R. Dua, S. Shrivastava, S. L. Shrivastava, and S. K. Srivastava, "Green chemistry and environmentally friendly technologies: a review. Middle-east," Journal of Scientific Research, vol. 11, pp. 846-855, 2012.

[25] W. Zhao, "Make the chemical industry clean with green chemistry: an interview with buxing han," National Science Review, vol. 5, no. 6, pp. 953-956, 2018.

[26] B. W. Books, "Greening chemistry and ecotoxicology towards sustainable environmental quality," Green Chemistry, vol. 21, no. 10, pp. 2575-2582, 2019.

[27] B. V. Badami, "Concept of green chemistry," Resonance, vol. 13, no. 11, pp. 1041-1048, 2008.

[28] R. Abdelaziz, D. Disci-Zayed, M. K. Hedayati et al., "Green chemistry and nanofabrication in a levitated leidenfrost drop," Nature Communications, vol. 4, no. 1, pp. 1-10, 2013.

[29] M. Tobiszewski, M. Marć, A. Gałuszka, and J. Namieśnik, "Green chemistry metrics with special reference to green analytical chemistry," Molecules, vol. 20, no. 6, pp. 1092810946, 2015.

[30] R. A. Sheldon, "Engineering a more sustainable world through catalysis and green chemistry," Journal of the Royal Society Interface, vol. 13, pp. 1-7, 2016.

[31] W. Abdussalam-Mohammed, A. Q. Ali, and A. O. Errayes, "Green chemistry: principles, applications, and disadvantages," Chemical Methodologies, vol. 4, pp. 408-423, 2020.

[32] J. Wisniak, "The history of catalysis. From the beginning to nobel prizes," Educación Química, vol. 21, no. 1, pp. 60-69, 2010.

[33] J. Šima, "Catalysis of a chemical processes: particular teaching aspects," AJCE, vol. 5, no. 2, pp. 1-15, 2015.

[34] P. K. Robinson, "Enzymes: principles and biotechnological applications," Essays in Biochemistry, vol. 59, pp. 1-41, 2015.

[35] M. Argyle and C. Bartholomew, "Heterogeneous catalyst deactivation and regeneration: a review," Catalysts, vol. 5, no. 1, pp. 145-269, 2015.

[36] Y. Ji, H. Yang, and W. Yan, "Strategies to enhance the catalytic performance of ZSM-5 zeolite in hydrocarbon cracking," Catalysts, vol. 7, pp. 1-31, 2017.

[37] L. P. De Oliveira, D. Hudebine, D. Gullaume, and J. J. Verstraete, "A review of kinetic modelling methodologies for complex processes," Oil \& Gas Science and Technology, vol. 71, pp. 1-49, 2016.

[38] L. Petrov, Problems and Challenges about Accelerated Testing of the Catalytic Activity of Catalysts, Springer, Berlin, Germany, 2002.

[39] P. J. Dyson and P. G. Jessop, "Solvent effects in catalysis: rational improvements of catalysts via manipulation of solvent interactions," Catalysis Science \& Technology, vol. 6, no. 10, pp. 3302-3316, 2016.

[40] A. Zecchina and E. Gloppo, "Heterogeneous, homogeneous, and enzyme catalysis: three branches of the same scientific chapter. Introductory remarks to the "concepts in catalysts" issue," Rendiconti Lincei, vol. 28, pp. S1-S4, 2017.

[41] R. Ye, T. J. Hurlburt, K. Sabyrov, S. Alayoglu, and G. A. Somorjai, "Molecular catalysis science: perspective on unifying the fields of catalysis," Proceedings of the National Academy of Sciences, vol. 113, no. 19, pp. 5159-5166, 2016.

[42] C. Hammond, D. Padovan, and G. Tarantino, "Porous metallosillicates for heterogeneous, liquid-phase catalysis: perspective and pertaining challenges," Royal Society Open Science, vol. 5, Article ID 171315, 2018.

[43] S. Waclawek, V. V. T. Padili, and M. Černík, "Major advantages and challenges in heterogeneous catalysis for environmental applications: a review," Ecological Chemistry and Engineering S, vol. 25, no. 1, pp. 9-34, 2018.

[44] J. C. Védrine, "Heterogeneous catalysis on metal oxides," Catalysts, vol. 7, pp. 1-25, 2017.

[45] A. Ledesma-Durán, S. I. Hernández, and I. SantamaríaHolek, "Effect of surface diffusion on adsorption-desorption and catalytic kinetics in irregular pores. II. Macro-kinetics," The Journal of Physical Chemistry C, vol. 121, no. 27, pp. 14557-14565, 2017.

[46] J. Heveling, "Heterogeneous catalytic chemistry by example of industrial applications," Journal of Chemical Education, vol. 89, no. 12, pp. 1530-1536, 2012.

[47] C. Hammond, "Intensification studies of heterogeneous catalysts: probing and overcoming catalyst deactivation during liquid phase operation," Green Chemistry, vol. 19, no. 12, pp. 2711-2728, 2017.

[48] Z. Xie, Z. Liu, Y. Wang, Q. Yang, L. Xu, and W. Ding, “An overview of recent development in composite catalysts from porous materials for various reactions and processes," International Journal of Molecular Sciences, vol. 11, no. 5, pp. 2152-2187, 2010

[49] M. G. T. C. Ribeiro, D. A. Costa, and A. A. S. C. Machado, "“Green star": a holistic green chemistry metric for evaluation of teaching laboratory experiments," Green Chemistry Letters and Reviews, vol. 3, no. 2, pp. 149-159, 2010.

[50] I. S. Pieta, W. S. Epling, A. Kazmierzuk, P. Lisowski, R. Nowakowski, and E. M. Serwicka, "Waste into fuel-catalyst and process development for MSW validation," Catalysts, vol. 8, pp. 1-16, 2018.

[51] T. Welton, "Solvents and sustainable chemistry," Proceedings of the Royal Society A: Mathematical, Physical and Engineering Sciences, vol. 471, pp. 1-26, 2015.

[52] W. Liu, K. Tian, H. Jiang, and H. Yu, "Facile synthesis of highly efficient and recyclable magnetic solid acid from biomass waste," Scientific Reports, vol. 3, pp. 1-7, 2013.

[53] B. W. Cue and J. Zhang, "Green process chemistry in the pharmaceutical industry," Green Chemistry Letters and Reviews, vol. 2, no. 4, pp. 193-211, 2009.

[54] F. Feng, J. Ye, Z. Cheng et al., "Cu-Pd/ $\gamma$-Al2O 3 catalyzed the coupling of multi-step reactions: direct synthesis of benzimidazole derivatives," RSC Advances, vol. 6, no. 76, pp. 72750-72755, 2016.

[55] S. Kandasamy, S. P. Samudrala, and S. Bhattacharya, "The route towards sustainable production of ethylene glycol from a renewable resource, biodiesel waste: a review," Catalysis Science \& Technology, vol. 9, no. 3, pp. 567-577, 2019.

[56] A. Kumar, K. Dhar, S. S. Kanwar, and P. K. Arora, "Lipase catalysis in organic solvents: advantages and applications," Biological Procedures Online, vol. 18, pp. 1-11, 2016.

[57] G. Pathak, D. Das, K. Rajkumari, and L. Rokhum, "Exploiting waste: towards a sustainable production of biodiesel using Musa acuminata peel ash as a heterogeneous catalyst," Green Chemistry, vol. 20, no. 10, pp. 2365-2373, 2018.

[58] A. D. Pike and A. S. Weller, "Organometallic synthesis, reactivity and catalysis in the solid state using well-defined 
single-site-species," Philosophical Transactions of the Royal Society A: Mathematical, Physical and Engineering Sciences, vol. 373, no. 2037, Article ID 20140187, 2015.

[59] M. Zaki, S. Hairat, and E. S. Aazam, "Scope of organometallic compounds based on transition metal-arene systems as anticancer agents: starting from the classical paradigm to targeting multiple strategies," RSC Advances, vol. 9, no. 6, pp. 3239-3278, 2019.

[60] M. K. Samantarav, E. Pump, A. Bendjeriou-Sedjerari et al., "Surface organometallic chemistry in heterogeneous catalysis," Chemical Society Reviews, vol. 47, pp. 8403-8437, 2018.

[61] E. V. Gusevskaya, "Organometallic catalysis: some contributions to organic synthesis," Química Nova, vol. 26, no. 2, pp. 242-248, 2003.

[62] A. G. M. Barrett, M. R. Crimmin, M. S. Hill, and P. A. Procopiou, "Heterofunctionalization catalysis with organometallic complexes of calcium, strontium and barium," Proceedings of the Royal Society A: Mathematical, Physical and Engineering Sciences, vol. 466, no. 2116, pp. 927-963, 2010.

[63] D. Wang and D. Astruc, "Dendritic catalysis- basic concepts and recent trends," Coordination Chemistry Reviews, vol. 257, no. 15-16, pp. 2317-2334, 2013.

[64] E. Antolini, "Palladium in fuel cell catalysis," Energy \& Environmental Science, vol. 2, no. 9, pp. 915-931, 2009.

[65] C. Qin, J. Wang, D. Yang, B. Li, and C. Zhang, "Proton exchange membrane fuel cell reversal: a review," Catalysts, vol. 6 , no. 12, p. 197, 2016.

[66] O. T. Holton and J. W. Stevenson, "The role of platinum in proton exchange membrane fuel cells evaluation of platinum's unique properties for use in both the anode and cathode of a proton exchange membrane fuel cell," Platinum Metals Review, vol. 57, no. 4, pp. 259-271, 2013.

[67] E. Remy, Y. R. J. Thomas, L. Guetaz, F. Souda-Onana, P. Jacques, and M. Heltzmann, "Optimization and tunability of $2 \mathrm{D}$ graphene and $1 \mathrm{D}$ carbon nanotube electrocatalysts structure for PEM fuel cells," Catalysts, vol. 8, no. 9, p. 377, 2018.

[68] S. Taylor, E. Fabbri, P. Levecque, T. J. Schmidt, and O. Conrad, "The effect of platinum loading and surface morphology on oxygen reduction activity," Electrocatalysis, vol. 7, no. 4, pp. 287-296, 2016.

[69] J. Chen, H. Zheng, J. Kang, F. Yang, Y. Cao, and M. Xiang, "An alkaline direct oxidation glucose fuel cell using threedimensional structural $\mathrm{Au} / \mathrm{Ni}$-foam as catalytic electrodes," RSC Advances, vol. 7, no. 5, pp. 3035-3042, 2017.

[70] S. Lu, J. Pan, A. Huang, L. Zhuang, and J. Lu, "Alkaline polymer electrolyte fuel cells completely free from noble metal catalysts," Proceedings of the National Academy of Sciences, vol. 105, no. 52, pp. 20611-20614, 2008.

[71] S. Gazi, W. K. Hung Ng, R. Ganguly et al., "Selective photocatalytic C-C bond cleavage under ambient conditions with earth abundant vanadium complexes," Chemical Science, vol. 6, no. 12, pp. 7130-7142, 2015.

[72] D. Walsh, N. M. Sanchez-Ballester, V. P. Ting, S. R. Hall, L. R. Terry, and M. T. Weller, "Visible light promoted photocatalytic water oxidation: effect of metal oxide catalyst composition and light intensity," Catalysis Science \& Technology, vol. 5, no. 10, pp. 4760-4764, 2015.

[73] X. Lang, X. Chen, and J. Zhao, "Heterogeneous visible light photocatalysis for selective organic transformations," Chemical Society Reviews, vol. 43, no. 1, pp. 473-486, 2014.
[74] D. Pei and J. Luan, "Development of visible light-responsive sensitized photocatalysts," International Journal of Photoenergy, vol. 2012, Article ID 262831, 13 pages, 2012.

[75] C. K. Prier, D. A. Rankic, and D. W. C. MacMillan, "Visible light photoredox catalysis with transition metal complexes: applications in organic synthesis," Chemical Reviews, vol. 113, no. 7, pp. 5322-5363, 2013.

[76] M. D. Ryan, R. M. Pearson, T. A. French, and G. M. Miyake, "Impact of light intensity on control in photoinduced organocatalyzed atom transfer radical polymerization," Macromolecules, vol. 50, no. 12, pp. 4616-4622, 2017.

[77] A. Sagadevan, K. C. Hwang, and M. Su, "Singlet-oxygenmediated selective $\mathrm{C}-\mathrm{H}$ bond hydroperoxidation of ethereal hydrocarbons," Nature Communications, vol. 8, no. 1, 2017.

[78] J. Bresien, T. Kröger-Badge, S. Lochbrunner et al., "A chemical reaction controlled by light-activated molecular switches based on hetero-cyclopentanediyls," Chemical Science, vol. 10, no. 12, pp. 3486-3493, 2019.

[79] S. Trashin, V. Rahemi, K. Ramji, U. Neven, S. M. Gorun, and K. De Wael, "Singlet oxygen-based electrosensing by molecule photosensitizers," Nature Communications, vol. 8, no. 1, 2017.

[80] G. Panzarasa and G. Soliveri, "Photocatalytic lithography," Applied Sciences, vol. 9, no. 7, p. 1266, 2019.

[81] R. Singh, M. Kumar, A. Mittal, and P. K. Mehta, "Microbial enzymes: industrial progress in $21^{\text {st }}$ century," 3 Biotech, vol. 6 , no. 2, 2016.

[82] S. Raveendran, B. Parameswaran, S. B. Ummalyma et al., "Applications of microbial enzymes in food industry," Food Technology and Biotechnology, vol. 56, no. 1, pp. 16-30, 2018.

[83] S. K. Silverman, "Catalytic DNA: scope, applications, and biochemistry of deoxyribozymes," Trends in Biochemical Sciences, vol. 41, no. 7, pp. 595-609, 2016.

[84] T. Nagamune, "Biomolecular engineering for nanobio/ bionanotechnology," Nano Convergence, vol. 4, no. 1, 2017.

[85] A. Z. Fadhel, P. Pollet, C. L. Liotta, and C. A. Eckert, "Combining the benefits of homogeneous and heterogeneous catalysis with tunable solvents and nearcritical water," Molecules, vol. 15, no. 11, pp. 8400-8424, 2010.

[86] J. Meyer, A. S. Meyer, T. Jesionowski, and M. Pinelo, "A general overview of support materials for enzyme immobilization: characteristics, properties, practical utility," Catalysts, vol. 8, no. 2, p. 92, 2018.

[87] H. Bisswanger, "Enzyme assays," Perspectives in Science, vol. 1, no. 1-6, pp. 41-55, 2014.

[88] K. Hemalatha, G. Madhumitha, A. Kajbafvala, N. Anupama, R. Sompalle, and S. Mohana Roopan, "Function of nanocatalyst in chemistry of organic compounds revolution: an overview," Journal of Nanomaterials, vol. 2013, pp. 1-23, 2013.

[89] S. Chaturvedi, P. N. Dave, and N. K. Shah, "Applications of nano-catalyst in new era," Journal of Saudi Chemical Society, vol. 16, no. 3, pp. 307-325, 2012.

[90] N. Sharma, H. Ojha, A. Bharadwaj, D. P. Pathak, and R. K. Sharma, "Preparation and catalytic applications of nanomaterials: a review," RSC Advances, vol. 5, no. 66, pp. 53381-53403, 2015.

[91] S. Olveira, S. P. Forster, and S. Seeger, "Nanocatalysis: academic discipline and industrial realities," Journal of Nanotechnology, vol. 2014, Article ID 324089, 19 pages, 2014.

[92] J. Wu, X. Wang, Q. Wang et al., "Nanomaterials with enzyme-like characteristics (nanozymes): next-generation artificial enzymes (II)," Chemical Society Reviews, vol. 48, no. 4, pp. 1004-1076, 2019. 
[93] S. Singh, "Nanomaterials exhibiting enzyme-like properties (nanozymes): current advances and future perspectives," Frontiers in Chemistry, vol. 7, pp. 1-10, 2019.

[94] H. Y. Shin, T. J. Park, and M. I. Kim, "Recent research trends and future prospects in nanozymes," Journal of Nanomaterials, vol. 2015, Article ID 756278, 11 pages, 2015.

[95] V. V. Pagar and T. V. RajanBabu, "Tandem catalysis for asymmetric coupling of ethylene and enynes to functionalized cyclobutanes," Science, vol. 361, no. 6397, pp. 68-72, 2018.

[96] M. Roche, A. Hamze, J. Brion, and M. Alami, "Catalytic three-component one-pot reaction of hydrazones dihaloarenes, and amines," Organic Letters, vol. 15, no. 1, pp. 128-151, 2013.

[97] N. Ríos-Lombardía, J. García-Álvarez, and J. GonzálezSabín, "One-pot combination of metal- and bio-catalysts in water for the synthesis of chiral molecules," Catalysts, vol. 8, no. 2, p. 75, 2018.

[98] Y. Wang and H. Zhao, "Tandem reactions combining biocatalysts and chemical catalysts for asymmetric synthesis," Catalysts, no. 6, pp. 1-21, 2016.

[99] W. Hordijk and M. Steel, "Autocatalytic networks at the basis of life's origin and organization,” Life, vol. 8, pp. 1-12, 2018.

[100] F. L. Sousa, W. Hordijk, M. Steel, and W. F. Martin, "Autocatalysis sets in E. coli mechanism," Journal of Systems Chemistry, vol. 6, no. 1, 2015.

[101] A. J. Bissette and S. P. Fletcher, "Novel applications of physical autocatalysis," Origins of Life and Evolution of Biospheres, vol. 45, no. 1-2, pp. 21-30, 2015.

[102] S. Corezzi, F. Sciortino, and C. Dé Michele, "Exploiting limited variance patchy to understand autocatalytic kinetics," Nature Communications, vol. 9, pp. 1-10, 2018.

[103] S. V. Singh, Z. Ming, P. S. Fennel, N. Shah, and E. J. Anthony, "Progress in biofuel production from gasification," Progress in Energy and Combustion Science, vol. 61, pp. 189-248, 2017.

[104] S. Ojala, N. Koivikko, T. Laitinen et al., "Utilization of volatile organic compounds as an alternative for destructive abatement," Catalysts, vol. 5, no. 3, pp. 1092-1151, 2015.

[105] S. Xing, P. Lv, J. Wang et al., "One-step hydroprocessing of fatty acids into renewable aromatic hydrocarbons over $\mathrm{Ni} /$ HZSM-5: insights into the major reaction pathways," Physical Chemistry Chemical Physics, vol. 19, no. 4, pp. 2961-2973, 2017.

[106] I. A. Reşitoğlu, K. Altinişik, and A. Keskin, “The pollutant emissions from diesel-engine vehicles and exhaust after treatment systems," Clean Technologies and Environmental Policy, vol. 17, no. 1, pp. 15-27, 2015.

[107] A. Fornalczyk, M. Saternus, and J. Willner, "The influence of platinum washing-out time on its recovery from used auto catalytic converters," Metalurgija -Sisak then Zagreb, vol. 53, pp. 349-352, 2014.

[108] J. Hu, F. Yu, and Y. Lu, "Application of fischer-tropsch synthesis in biomass to liquid conversion," Catalysts, vol. 2, no. 2, pp. 303-326, 2012.

[109] W. D. Shafer, M. K. Gnanamani, U. M. Graham et al., "Fischer-tropsch; product selectivity- the fingerprint of synthetic fuels," Catalysts, vol. 9, pp. 11-57, 2019.

[110] M. Alfano and C. Cavazza, "The biologically mediated watergas shift reaction: structure, function and biosynthesis of monofunctional [NiFe]-Carbon monoxide dehydrogenases," Sustainable Energy \& Fuels, vol. 2, no. 8, pp. 1653-1670, 2018.

[111] J. C. Serrano-Ruiz, E. V. Ramos-Fernández, and A. Sepúlveda-Escribano, "From biodiesel and bioethanol to liquid hydrocarbonfuels: new hydrotreating and advanced microbial technologies," Energy \& Environmental Science, vol. 5, no. 2, pp. 5638-5652, 2012.

[112] J. Daniell, M. Köpke, and S. Simpson, "Commercial biomass syngas fermentation,” Energies, vol. 5, no. 12, pp. 5372-5417, 2012.

[113] J. Milledge, B. Smith, P. Dyer, and P. Harvey, "Macroalgaederived biofuel: a review of methods of energy extraction from seaweed biomass," Energies, vol. 7, no. 11, pp. 71947222, 2014.

[114] L. Wu, T. Zhang, H. Wang, C. Tang, and L. Zhang, "A novel fabricating process of catalytic gas sensor based on droplet generating technology," Micromachines, vol. 10, pp. 1-11, 2019.

[115] Z. Zhang and G. W. Huber, "Catalytic oxidation of carbohydrates into organic acids and furan chemicals," Chemical Society Reviews, vol. 47, no. 4, pp. 1351-1390, 2018.

[116] M. A. Betiha, N. G. Kandile, A. M. Badawi, S. M. Solyman, and A. S. Afify, "Oxidation of p-toluic acid to terephthalic acid via a bromine-free process using nano manganese and manganese-copper mixed oxides," New Journal of Chemistry, vol. 42, no. 8, pp. 6343-6353, 2018.

[117] S. Li, J. A. Medrano, V. Hessel, and F. Galucci, "Recent progress of plasma-assisted nitrogen fixation research: a review," Processes, vol. 6, pp. 1-25, 2018.

[118] J. Liu, X. Ma, Y. Li, Y. Wang, H. Xiao, and J. Li, "Heterogeneous $\mathrm{Fe}_{3}$ single-cluster catalyst for ammonia synthesis via an associative mechanism," Nature Communications, vol. 1610, no. 1, pp. 1-9, 2018.

[119] M. S. Abbas-Abadi, "The production of high efficiency ziegler-natta catalyst with dual active sites nature using cyclohexyl chloride as a promoter with super activity and produced superior polyethylene with controllable molecular weight distribution," Designed Monomers and Polymers, vol. 20, no. 1, pp. 524-531, 2017.

[120] A. Díaz, R. Katsarava, and J. Puiggalí, "Properties and applications of biodegradable polymers derived from diols and dicarboxylic acids: from polyesters to poly(ester amide)s," International Journal of Molecular Sciences, vol. 15, no. 5, pp. 7064-7123, 2014

[121] R. Sheldon, "Catalytic reactions in ionic liquids," Chemical Communications, no. 23, pp. 2399-2407, 2001.

[122] W. Sebati and S. S. Ray, "Advances in nanostructures metalencapsulated porous organic- polymer composites for catalyzed organic chemical synthesis," Catalysts, vol. 8, pp. 1-27, 2018.

[123] X.-F. Wu, X. Fang, L. Wu, R. Jackstell, H. Neumann, and M. Beller, "Transition-metal-catalyzed carbonylation reactions of olefins and alkynes: a personal account," Accounts of Chemical Research, vol. 47, no. 4, pp. 1041-1053, 2014.

[124] L. A. Nguyen, H. He, and C. Pham-Huy, "Chiral drugs: an overview," International Journal of Biomedical Science: IJBS, vol. 2, no. 2, pp. 85-100, 2006.

[125] A. Petri, V. Colonna, and O. Piccolo, "Asymmetric synthesis of a high added value chiral amine using immobilized $\omega$-transaminases," Beilstein Journal of Organic Chemistry, vol. 15, pp. 60-66, 2019.

[126] M. G. Vinogradov, O. V. Turova, and S. G. Zlotin, "Recent advances in the asymmetric synthesis of pharmacologyrelevant nitrogen heterocycles via stereoselective aza-michael reactions," Organic \& Biomolecular Chemistry, vol. 17, no. 15, pp. 3670-3708, 2019.

[127] W. Cao, X. Feng, and X. Liu, "Reversal of enantioselectivity in chiral metal complex-catalyzed asymmetric reactions," 
Organic \& Biomolecular Chemistry, vol. 17, no. 27, pp. 6538-6550, 2019.

[128] F. Sonmez, H. Ercan, H. Genc, M. Arslan, M. Zengin, and M. Kucukislamoglu, "Hydrogenation of some vegetable oils by scrap automobile catalyst," Journal of Chemistry, vol. 2013, pp. 1-4, 2013.

[129] J. Chapman, A. E. Ismail, and C. Z. Dinu, "Industrial applications of enzymes: recent techniques, and outlooks," Catalysts, vol. 8, pp. 1-26, 2018.

[130] K. Daiha, R. Angeli, S. Dias de Oliveira, and R. V. Almeida, "Are lipases still important biocatalysts? A study of scientific publications and patents for technological forecasting," PLoS One, vol. 10, pp. 1-20, 2015.

[131] P. Fernandes, "Enzymes in food processing: a condensed overview on strategies for better biocatalysts," Enzyme Research, vol. 2010, Article ID 862537, 19 pages, 2010.

[132] H. Dai, "Environmental catalysis: a solution for the removal of atmospheric pollutants," Science Bulletin, vol. 60, no. 19, pp. 1708-1710, 2015.

[133] Q. Sun, S. Wang, B. Aguila, X. Meng, S. Ma, and F. Xiao, "Creating solvation environments in heterogeneous catalysts for efficient biomass conversion," Nature Communications, vol. 9, no. 1, 2018.

[134] T. Batakliev, V. Georgiev, M. Anachkov, S. Rakovsky, and S. Rakovsky, "Ozone decomposition," Interdisciplinary Toxicology, vol. 7, no. 2, pp. 47-59, 2014.

[135] S. B. Nimse and D. Pal, "Free radicals, natural antioxidants, and their reaction mechanisms," RSC Advances, vol. 5, no. 35, pp. 27986-28006, 2015.

[136] A. Phaniendra, D. B. Jestadi, and L. Periyasamy, "Free radicals: properties, sources, targets, and their implication in various diseases," Indian Journal of Clinical Biochemistry, vol. 30, no. 1, pp. 11-26, 2015.

[137] F. S. Rowland, "Stratospheric ozone depletion," Philosophical Transactions of the Royal Society B: Biological Sciences, vol. 361, no. 1469, pp. 769-790, 2006.

[138] C. T. McElroy and P. F. Fogal, "Ozone: from discovery to protection,” Atmosphere-Ocean, vol. 46, no. 1, pp. 1-13, 2008.

[139] Bismuth, 2020, http://www.rsc.or/periodc-table/element/83/ bismuth.

[140] D. Keogan and D. Griffith, "Current and potential applications of bismuth-based drugs," Molecules, vol. 19, no. 9, pp. 15258-15297, 2014.

[141] J. M. Bothwell, S. W. Krabbe, and R. S. Mohan, "Applications of bismuth(III) compounds in organic synthesis," Chemical Society Reviews, vol. 40, no. 9, pp. 4649-4707, 2011.

[142] R. Wang, H. Li, and H. Sun, "Bismuth: environmental pollution and health effects," Encyclopedia of Environmental Health, pp. 415-423, 2019.

[143] Y. H. Jang and W. A. Goddard, "Mechanism of selective oxidation and ammoxidation of propene on bismuth molybdates from DFT calculations on model clusters," The Journal of Physical Chemistry B, vol. 106, no. 23, pp. 5997$6013,2002$.

[144] V. K. Srivastava, M. Maiti, G. C. Basak, and R. V. Jasra, "Role of catalysis in sustainable production of synthetic elastomers," Journal of Chemical Sciences, vol. 126, no. 2, pp. 415-427, 2014.

[145] T. Hanna, "The role of bismuth in the SOHIO process," Coordination Chemistry Reviews, vol. 248, no. 5-6, pp. 429-440, 2004.

[146] T. Ollevier, "New trends in bismuth-catalyzed synthetic transformations," Organic \& Biomolecular Chemistry, vol. 11, no. 17, pp. 2740-2755, 2013.
[147] J. Luan, L. Zhang, and Z. Hu, "Synthesis, properties characterization and applications of various organobismuth compounds," Molecules, vol. 16, no. 5, pp. 4191-4230, 2011.

[148] X. Liu, M. Xião, L. Xu, Y. Miao, and R. Ouyang, "Characteristics, applications and determination of bismuth," Journal of Nanoscience and Nanotechnology, vol. 16, no. 7, pp. 6679-6689, 2016.

[149] M. Jaishankar, T. Tseten, N. Anbalagan, B. B. Mathew, and K. N. Beeregowda, "Toxicity, mechanism and health effects of some heavy metals," Interdisciplinary Toxicology, vol. 7, no. 2, pp. 60-72, 2014.

[150] K. S. Egorova and V. P. Ananikov, "Toxicity of metal compounds: knowledge and myths," Organometallics, vol. 36, no. 21, pp. 4071-4090, 2017.

[151] R. Pamphlett and S. K. Jew, "Heavy metals in locus ceruleus and motor neurons in motor neuron disease," Acta Neuropathologica Communications, vol. 1, p. 81, 2013.

[152] Y. Song, H. Jiang, H. Bi et al., "Multifunctional bismuth oxychloride/mesoporous silica composites for photocatalysis, antibacterial test, and simultaneous stripping analysis of heavy metals," ACS Omega, vol. 3, no. 1, pp. 973-981, 2018.

[153] B. Sharma, S. Singh, and N. J. Siddiqi, "Biomedical implications of heavy metals induced imbalances in redox systems," BioMed Research International, vol. 2014, Article ID 640754, 26 pages, 2014

[154] W. Xue, Z. Wang, Y. Liang, H. Xu, L. Liu, and J. Dong, "Promoting role of bismuth on hydrotalcite supported platinum catalysts in aqueous phase oxidation of glycerol to dihydroxyacetone," Catalysts, vol. 8, pp. 1-12, 2018.

[155] L. Wang, B. Peng, L. Peng, X. Guo, Z. Xie, and W. Ding, "Mesostructural Bi-Mo-O catalyst: correct leading to high performance," Science Reports, vol. 3, pp. 1-6, 2013.

[156] S. Khademinia, M. Behzad, A. Alemi, M. Dolatyari, and S. M. Sajjadi, "Catalytic performance of bismuth pyromanganate nanocatalyst for biginelli reactions," RSC Advances, vol. 5, no. 87, pp. 71109-71114, 2015.

[157] Y. Wu, X. Duan, Z. Li et al., "The modification of Pt/graphene composites with oxophilic metal $\mathrm{Bi}\left(\mathrm{Bi}_{2} \mathrm{O}_{3}\right)$ and its dual-functional electro- photo catalytic performance," Catalysts, vol. 8, pp. 1-15, 2018.

[158] J. A. Barón-Jaimez, J. L. Marulanda-Arévalo, and J. J. BarbaOrtega, "Electrodes friendly with the environment for detect heavy metal," DYNA, vol. 81, no. 187, pp. 122-128, 2014.

[159] H. Wang, G. Zhao, Y. Yin, Z. Wang, and G. Liu, "Screenprinted electrode modified by bismuth $/ \mathrm{Fe}_{3} \mathrm{O}_{4}$ nanoparticles/ ionic liquid composite using internal standard normalization for accurate determination of Cd(II) in soil," Sens, vol. 18, pp. 1-13, 2018.

[160] A. Economou, "Screen-printed electrodes modified with "green" metals for electrochemical stripping analysis of toxic elements," Sensors, vol. 18, pp. 1-13, 2018.

[161] L. Pujol, D. Evrald, K. Groenen-Serrano, M. Freyssinier, A. Ruffien-Cizsak, and P. Gros, "Electrochemical sensors and devices for heavy metals assay in water: the French groups' contributions," Frontiers in Chemistry, vol. 2, pp. 1-24, 2014.

[162] R. Xie, L. Zhou, C. Lan et al., "Nanostructured carbon black for simultaneous electrochemical determination of trace lead and cadmium by different pulse stripping voltammetry," Royal Society Open Science, vol. 5, pp. 1-10, 2018.

[163] R. Ouyang, W. Zhang, S. Zhou et al., "Improved Bi film wrapped single walled carbon nanotubes for ultrasensitive electrochemical detection of trace $\mathrm{Cr}(\mathrm{VI})$," Electrochimica Acta, vol. 113, pp. 686-693, 2013. 
[164] S. Palisoc, A. J. Gonzales, A. Pardilla, L. Racines, and M. Natividad, "Electrochemical detection of lead and cadmium UHT-processed milk using bismuth nanoparticles/ nafion ${ }^{\circledR}$-modified pencil graphite electrode," Sensing and Bio-Sensing Research, vol. 23, pp. 1-8, 2019.

[165] C. Dossi, D. Monticelli, A. Pozzi, and S. Recchia, "Exploiting chemistry to improve performance of screen-printed, bismuth film electrodes (SP-BIFE)," Biosensors, vol. 6, no. 3, p. $38,2016$.

[166] J. H. Kim, H. Park, C.-H. Hsu, and J. Xu, "Facile synthesis of bismuth sulfide nanostructures and morphology tuning by a biomolecule," The Journal of Physical Chemistry C, vol. 114, no. 21, pp. 9634-9639, 2010.

[167] I. G. David, D.-E. Popa, and M. Buleandra, "Pencil graphite electrodes: a versatile tool in electroanalysis," Journal of Analytical Methods in Chemistry, vol. 2017, pp. 1-22, 2017.

[168] H. Guo, H. Yin, X. Yan et al., "Pt-Bi decorated nanoporous Gold for high performance direct glucose fuel cell," Scientific Reports, vol. 6, no. 1, pp. 1-9, 2016.

[169] E. Casado-Rivera, D. J. Volpe, L. Alden et al., "Electrocatalytic activity of ordered intermetallic phases for fuel cell applications," Journal of the American Chemical Society, vol. 126, no. 12, pp. 4043-4049, 2004.

[170] H. Zhai, S. Shang, L. Zheng et al., "Efficient visible-light photocatalytic properties in low-temperature $\mathrm{Bi}-\mathrm{Nb}-\mathrm{O}$ system photocatalysts," Nanoscale Research Letters, vol. 11, no. $1,2016$.

[171] T. Saison, N. Chemin, C. Chanéac et al., " $\mathrm{Bi}_{2} \mathrm{O}_{3}, \mathrm{BiVO}_{4}$, and $\mathrm{Bi}_{2} \mathrm{WO}_{6}$ : impact of surface properties on photocatalytic activity under visible light," The Journal of Physical Chemistry C, vol. 115, no. 13, pp. 5657-5666, 2011.

[172] D. A. Solís-Casados, L. Escobar-Alarcón, V. Alvarado-Pérez, and E. Haro-Poniatowski, "Photocatalytic activity under simulated sunlight of $\mathrm{Bi}$-modified $\mathrm{TiO}_{2}$ thin films obtained by sol gel," International Journal of Photoenergy, vol. 2018, Article ID 8715987, 9 pages, 2018.

[173] X. Wang, H. Liu, C. Liu et al., "Recent advances and applications of semiconductor photocatalytic technology," Applied Sciences, vol. 9, pp. 1-43, 2019.

[174] M. Salimi, M. Behbahani, H. R. Sobhi et al., "A new nanophotocatalyst based on $\mathrm{Pt}$ and $\mathrm{Bi}$ co-doped $\mathrm{TiO}_{2}$ for efficient visible-light photo degradation of amoxicillin," New Journal of Chemistry, vol. 43, no. 3, pp. 1562-1568, 2019.

[175] M. Nischk, P. Mazierski, Z. Wei et al., "Enhanced photocatalytic, electrochemical and photoelectrochemical properties of $\mathrm{TiO} 2$ nanotubes arrays modified with $\mathrm{Cu}, \mathrm{AgCu}$ and Bi nanoparticles obtained via radiolytic reduction," Applied Surface Science, vol. 387, pp. 89-102, 2016.

[176] S. Shenawi-Khalil, V. Uvarov, E. Menes, I. Popov, and Y. Sasson, "New efficient visible light photocatalyst based on heterojunction of BiOCl-bismuth oxyhydrate," Applied Catalysis A: General, vol. 413-414, pp. 1-9, 2012.

[177] Y. Lei, X. Chen, C. Xu, Z. Dai, and K. Wei, "Enhanced catalytic performance in the gas-phase epoxidation of propylene over Ti-modified $\mathrm{MoO}_{3}-\mathrm{Bi}_{2} \mathrm{SiO} 5 / \mathrm{SiO}_{2}$ catalysts," Journal of Catalysis, vol. 321, pp. 100-112, 2015.

[178] O. Marvi and H. T Nahzomi, "Grinding solvent-free paalknorr pyrrole synthesis on smectites as recyclable and green catalysts," Bulletin of the Chemical Society of Ethiopia, vol. 32, no. 1, pp. 139-147, 2018.

[179] K. Aghapoor, L. Ebadi-Nla, F. Mohsenzadeh, M. M. Morad, Y. Balayar, and H. R. Darabi, "Silica-supported bismuth(III) chloride as a new recyclable heterogeneous catalyst for the paal-knorr pyrrole synthesis," Journal of Organometallic Chemistry, pp. 708-709, 2012.

[180] B. Xu, G. Li, J. Li, and Y. Shi, "Total synthesis of the proposed structure of marineosin A," Organic Letters, vol. 18, no. 9, pp. 2028-2031, 2016.

[181] A. Balakrishna, A. Aguiar, P. J. M. Sobral, M. Y. Wani, J. Almeida e Silva, and A. J. F. N. Sobral, "Paal-knorr synthesis of pyrroles: from conventional to green synthesis," Catalysis Reviews, vol. 61, no. 1, pp. 84-110, 2018.

[182] C.-C. Chen, C.-L. Lin, and L.-C. Chen, "A binary palladiumbismuth nanocatalyst with high activity and stability for alkaline glucose electrooxidation," Journal of Power Sources, vol. 287, pp. 323-333, 2015.

[183] X. Yan, X. Ge, and S. Gui, "Pt-decorated nanoporous Gold for glucose electrooxidation in neutral and alkaline solutions," Nanoscale Research Letters, vol. 6, no. 1, 2011.

[184] D. Shao, L. Zhang, S. Sun, and W. Wang, "Oxygen reduction reaction for generating $\mathrm{H}_{2} \mathrm{O}_{2}$ through a piezo-catalytic process over bismuth oxychloride," ChemSusChem, vol. 11, no. 3, pp. 527-531, 2018.

[185] H. Lei, H. Zhang, Y. Z, X. Dong, Y. Ja, and F. Wang, "Synergistic photocatalysis/piezocatalysis of bismuth oxychloride for degradation of organic pollutants," Journal of Alloys and Compounds, vol. 809, pp. 1-8, 2019.

[186] M. Ismail, Z. Wu, L. Zhang et al., "High-efficient synergy of piezocatalysis and photocatalysis in bismuth oxychloride nanomaterial for dye decomposition," Chemosphere, vol. 228, pp. 212-218, 2019.

[187] Z. Wu, W. Luo, H. Zhang, and Y. Jia, "Strong pyro-catalysis of shape -controllable bismuth oxychloride nanomaterial for waste water remediation," Applied Surface Science, vol. 513, pp. 1-7, 2020.

[188] J. Wu, W. Mao, Z. Wu et al., "Strong pyro-catalysis of pyroelectric $\mathrm{BiFeO}_{3}$ nanoparticles under a room-temperature cold-hot alternation," Nanoscale, vol. 8, no. 13, pp. 73437350, 2016.

[189] H. You, Y. Jia, Y. Wu, F. Wang, H. Huang, and Y. Wang, "Room temperature pyro-catalytic hydrogen generation of 2D few-black phosphorene under cold-hot alteration," $\mathrm{Na}$ ture Communications, vol. 9, no. 1, 2018.

[190] S. Li, Z. Zhao, J. Zhao, Z. Zhang, X. Li, and J. Zhang, "Recent advances f ferro-, piezo-, and pyroelectric nanomaterials for catalytic applications," ACS Applied Nano Materials, vol. 3, no. 2, pp. 1083-1079, 2020.

[191] I. E. Uflyand, V. A. Zhinzhilo, and V. E. Burlakova, "Metalcontaining nanomaterials as lubricant additives: state-of-theart and future development," Friction, vol. 7, no. 2, pp. 93116, 2019.

[192] P. Gonzalez-Rodriguez, K. J. H. van den Nieuwenhuijzen, W. Lette, D. J. Schipper, and J. E. ten Elshof, "Tribochemistry of bismuth and bismuth salts for solid lubrication," ACS Applied Materials \& Interfaces, vol. 8, no. 11, pp. 7601-7606, 2016.

[193] M. I. De B. Bouchet, J. M. Martin, C. Forest et al., "Tribochemistry of unsaturated fatty acids as friction modifiers in (bio) fuel," RSC Advances, vol. 7, pp. 33120-33131, 2017.

[194] R. Zhang, D. Sn, R. Zhang et al., "Gold nanoparticle-polymer nanocomposites synthesized by room temperature atmospheric pressure plasma and their potential for fuel cell electrocatalytic applications," Science Reports, vol. 7, pp. 1-9, 2017.

[195] H. Meng, D. Zeng, and F. Xie, "Recent development of Pdbased electrocatalysts for proton exchange membrane fuel cells," Catalysts, vol. 5, no. 3, pp. 1221-1274, 2015. 
[196] X. Ren, Q. Lv, L. Liu et al., "Current progress of Pt and Ptbased electrocatalysts used for fuel cells," Sustainable Energy \& Fuels, vol. 4, no. 1, pp. 15-30, 2020.

[197] Y. Zheng, X. Wan, X. Cheng, K. Cheng, Z. Dai, and Z. Liu, "Advanced catalytic materials for ethanol oxidation in direct ethanol fuel cells," Catalstys, vol. 10, pp. 1-22, 2020. 